\title{
Oral-Based Christian-Marapu Interreligious Engagement: Manawara as A Shared Virtue for Common Liberation
}

\author{
Krisharyanto Umbu Deta \\ Center for Religious and Cross-cultural Studies, Graduate School, Universitas Gadjah Mada, Yogyakarta 55281, \\ Indonesia. Email: krisharyantoud@gmail.com
}

\begin{abstract}
This has been prevalent that the discourse of interreligious dialogue has been overwhelmingly dominated by the elites in the formal spheres. It even seems to be the only standard to examine the issues of interreligious relations, without taking into account the diverse modes of everyday engagements among the people. This then raises the recognition that there is actually no single pattern for interreligious engagement since it would be always contextual according to its distinctive context. It therefore implies the need to learn more from the localities to develop more contextual interreligious engagement. In this regard, this work will examine the interreligious engagement of Christianity and Marapu indigenous religion in Sumba. The data used in this work are based on the field research conducted in 2019 in Southwest Sumba. Observation and in depth interview with a number of Sumbanese Christians and Marapu are also conducted. The research finds that manawara (the teaching of love; compassion) as the potential basis for developing social engagement. The term manawara is used by Marapu people in their teaching, but since the term is a Sumbanese language, the Sumbanese Christians also translate their prominent teaching of love with that term. Manawara is then both scriptural-based for Christians, and oral-based for Marapu people.
\end{abstract}

Keywords: interreligious engagement, manawara, orality, sumbanese Christian, marapu indigenous religion

\section{Keterlibatan Antaragama Kristen-Marapu Berbasis Kelisanan: Manawara sebagai Kebijakan Bersama untuk Pembebasan Bersama}

\begin{abstract}
Abstrak
Wacana dialog antaragama selama ini telah didominasi sedemikian rupa oleh para elit dalam ruangruang formal. Hal itu bahkan menjadi seolah satu-satunya ukuran untuk membahas isu-isu hubungan antaragama, tanpa memperhitungkan keberagaman bentuk keterlibatan sehari-hari yang dihidupi secara nyata oleh orang-orang beragama yang merupakan subjek utama dalam topik tersebut. Dari sinilah kemudian muncul kesadaran bahwa sebenarnya tidak ada satu pola tertentu untuk keterlibatan antaragama karena ia akan selalu tergantung pada konteksnya yang unik. Hal ini menunjukkan bahwa penting untuk lebih banyak belajar dari lokalitas-lokalitas yang ada demi mengembangkan keterlibatan antaragama yang lebih kontekstual. Untuk itu, tulisan ini akan membahas keterlibatan antaragama Kristen dan Marapu di Sumba. Data yang digunakan dalam studi ini diperoleh dari sebuah penelitian lapangan pada tahun 2019 di Sumba Barat Daya yang dilakukan melalui observasi dan wawancara mendalam dengan sejumlah orang Sumba Kristen dan Marapu. Penelitian tersebut menemukan manawara (ajaran tentang kasih) sebagai basis potensial untuk mengembangkan keterlibatan yang ada. Istilah manawara digunakan oleh orang Marapu dalam ajaran mereka, namun karena istilah tersebut adalah sebuah kata dalam Bahasa Sumba, orang Sumba Kristen juga menerjemahkan ajaran kasih mereka dengan istilah manawara tersebut. Dengan demikian, manawara menjadi suatu ajaran yang basisnya skriptural, bagi orang Kristen, dan oral, bagi orang Marapu.
\end{abstract}

Kata Kunci: keterlibatan antaragama, manawara, kelisanan, orang Kristen Sumba, agama Marapu

*Naskah diterima September 2021, direvisi Oktober 2021, dan disetujui untuk diterbitkan November 2021

Dialog, 44(2), 2021, 178-189

https://jurnaldialog.kemenag.go.id,p-ISSN: 0126-396X, e-ISSN: 2715-6230

This is open access article under CC BY-NC-SA-License

(https://creativecommons.org/license/by-nc-sa/4.0/)

Dialog Vol. 44, No.2, Desember 2021 


\section{A. Introduction}

In Swidler's historical exploration of the process of how interreligious dialogue was gradually initiated, it is shown how (world) religions started to engage in dialogue as the paradigm about the 'truth' had shifted from being exclusive; absolute, static, monologic, to be 'relational' (Swidler, 2013, p. 11). However, in Sumba, the dialogue and engagement actually had been there without any specific efforts to endeavor it. Not until the coming of Christianity through colonialism, as well as other world religions through migration, that the Sumbanese society started to be divided and thus the challenges in the inter-religious encounter emerged. It is easier understood in the specific example of a Sumbanese family nowadays. In many cases, there will be different family members with different religions, mostly Christian and Marapu, living under one roof. This is because they are indeed a unit of family in which a part of it has been Christians and the rest keep holding their Marapu indigenous religion. In brief, it is not a gathering of people with different religions through the process of coming from different contexts to engage one another, but rather a natural group of a family at which religion comes as a tool for differentiation.

Many scholars also often encourage the religious people to have a dialogue, engage one another, and then make common action, but it actually has been, or at least had been, there in Sumba. The religion-based differentiation does not succeed dividing them to any boundaries, except the boundary of religion (Christianity) itself. This is because they know that they come from the same ancestor and thus the familybased relationship is stronger than the religion-based relationship. As Lattu argues, the collective memory of a common ancestor links cousinhood or co-descent who share the same cultural remembrance of the ancestry and thus courage some general sense of sharing a common present, in other words; the consciousness of being descended from the common ancestors forms the feeling of being connected (Lattu,
2014, p. 60). In short, dialogue, engagement, and cooperation have happened in the everyday encounter of Sumbanese Christians and Marapu.

If interreligious relations are mainly based on theological conversations according to the scriptures, doctrines, and the dialogue of the elites, as argued by Abu Nimer saying that scripture in many cases can function as a foundation providing faithful participants with direction and confidence (Abu-Nimer, 2002, p. 19), Lattu proposes the orality as a strong potential base for interreligious relationship especially in the grassroot level. As he argues, oral forms of collective memory in an orally-oriented society are more effective than scriptural and elite-based approaches to interreligious dialogue (Lattu, 2014, p. 1). Being rooted in a particular social context, people in a given area could create collective understanding and interreligious relationships through orality (Lattu, 2019a, p. 73). He adds that people will communicate more effectively through oral forms such as rituals, symbols, and verbalized narratives (Lattu, 2014, 2018, 2019a, p. 78). This idea comes from his observation on many Indonesian local experiences of interreligious engagements. As he strongly insists in the end of his recent work entitled "Beyond Interreligious Dialogue: Oral-based Interreligious Engagement in Indonesia", by taking into account the Indonesian experience of interreligious engagement, it would be clear that there is no single pattern for interreligious engagement since it would be always contextual according to its distinctive and unique context. Hence, this kind of local models of interreligious engagement implies the need to learn more from local people and develop more contextual interreligious engagement based on local context and values (Lattu, 2019a, p. 87).

Taking that challenging idea of engaging the locality, which is often considered primitive, to respond to the most contemporary challenges of religious pluralism at the local, national, and even global context, this work will examine the 
interreligious engagement of Christianity and Marapu indigenous religion in Sumba by accentuating manawara (the teaching of love; compassion) as the potential basis for developing the engagement. Manawara is a Sumbanese language word that could be translated as love and compassion. The term is used by Marapu people in their teaching, but since the term is a Sumbanese language, the Sumbanese Christians also translate their prominent teaching of love with manawara. Hence, both Christians and Marapu people use the same terminology to refer to their respective teachings. In that regard, manawara is both scriptural-based for Christians and oral-based for Marapu people. This teaching is seldom mentioned by Marapu people but really depicted in the harmonious life of Christians and Marapu people, not only at the extent of lip service but at the concrete practical extent seen in their cooperation on many occasions. This work therefore argues that manawara as a shared virtue would be really helpful, and should be taken into account seriously to be developed, in realizing mutual action for common liberation of the Sumbanese, both Christians and Marapu.

\section{B. Method}

The field data used in this work are based on a field research in 2019 in Southwest Sumba done through observation and in depth interview with a number of Sumbanese Christians and Marapu people. The data is analyzed through Lattu's oralbased interreligious engagement and Knitter's socially engaged dialogue as the cooperation of interreligious dialogue and social action. After describing the background, issues, and aims of this article in the introduction, this study will explore existing literature discussing interreligious engagement in relation to the social action for liberation. In the result and discussion section, manawara will be firstly examined as a shared virtue for both Sumbanese Marapu and Christians. That would lead to the next part in which the inferiority of orality and oral-based community would be revisited. This is to have a more just perception on how manawara, both as an oral and scriptural based teaching, exists and influences the encounter of Christianity and Marapu. This article, in the end, would be concluded with a call for common liberation as an inviting conclusion.

\section{Result and Discussion \\ Interreligious Engagement and Liberation}

In one of her prominent articles, Diana Eck prefers to use the 'interfaith' term and outlines five kinds of dialogue; dialogue of life - take and give relationships in the neighborhood, workplace, etc, dialogue of learning - the intentional study of other cultures and faiths for mutual learning and understanding, dialogue in community engaging with one another in shaping community and society, philosophical and theological dialogue - engaging with one another on the deepest and foundational issues of one's own faith, and dialogue within - reflection on what all that means for one's own faith with the awareness that there is also spiritual voices and perspectives within one's own self (Eck, 2017). This idea of dialogue is in line with the Vatican Council' categorization as quoted by Knitter; the dialogue of theology or the dialogue of head trying to get our heads straight together, the dialogue of spirituality or the dialogue of hearts seeking to bring our hearts into sync with each other, the dialogue of action or the dialogue of hands acting together to confront and resolve common problems, and the dialogue of life which takes place in which different religious people live in the same neighborhood (Knitter, 2013, p. 134).

Lattu (2014) mentions four forms of interreligious dialogue based on Roman Catholic Church's Pontifical Council for Interreligious Dialogue; the dialogue of life living in an open neighborly spirit, sharing joys, sorrows, human problems and preoccupations, the dialogue of actioncollaboration for the integral development and liberation of people, the dialogue of theological exchange - deepening understanding of respective religious heritages and appreciating the other's 
spiritual values, and the dialogue of religious experience - rooted on one's own religious tradition, share the spiritual riches, regarding to prayer, contemplation, faith and ways of searching for the Absolute or God. In a similar way, Indonesian Muslim scholars from the International Center of Islam and Pluralism, as mentioned by Lattu, insist that interreligious dialogue deals with dialogue about life, social work, and theological and spiritual matter which could be framed in the typology of 'believe' and 'behave' or dialogue as conversation and dialogue as praxis (Lattu, 2014, p. 212).

Lattu insists on the urgency to move from interreligious dialogue to interreligious engagement since the former is often understood as an official form of conversation which tends to not involve the grassroots. He explains the inadequacy of conversation by quoting Marc Gopin who argues that interreligious encounters could be rich in deeds, symbols, emotions, and shared work through which people could share their feelings and connect with others (Lattu, 2014, p. 220, 2016, p. 173; M. Gopin, 2002, pp. 34-37). In this sense, he adds, people can interact using their everyday cultural language and thus enable routine encounters. In those daily encounters, anxieties and hopes of the shared common concerns which are defined by many problems faced by the inter-religious communities in their daily life emerge, in other words; interreligious engagement develops from common concern and religious communities have to ground dialogue in concrete actions in which their elites are not only concern with religiousmoral matters in conversation (Banawiratma, 2002, p. 56; Lattu, 2014, p. 222, 2016, p. 171; A. S. Maarif et al., 2010, p. 19). Based on those considerations, Lattu proposes the use of 'interreligious engagement' which he perceives as a form of public interaction and common action aimed toward connecting people from different religions, yet remaining members of their (same) communities (Lattu, 2014, p. 225).

This idea of more preferring engagement, rather than dialogue, could be also connected to Knitter's thesis about the need to combine interreligious dialogue and social action (Knitter, 2013) or in the theological framework, liberation theology of religions, which is the combination of theology of religions and theology of liberation (Knitter, 1998). About the latter, for Knitter, theology of religions which responds to the problem of religious pluralism, and theology of liberation, which responds to the greater and more urgent problem of suffering and injustice, currently have been the most creative and revitalizing expressions of Christian life and thought (Knitter, 1998, p. 178). In arguing the necessity to cooperate both, he insists that, on one hand, for liberation theology is not only rooted in Latin America but also is to take root in Asia, it has to openly dialogue with Eastern religions. On the other hand, dialogue and pluralism, which are the most pivotal themes of theology of religions, should not be one's first concern nor should they be ends in themselves (Knitter, 1998, pp. 179-180).

Knitter argues that ideologized doctrines and practices firstly have to be detected and revised before the voice of God, either in the tradition or in the world or both, can really be heard, while ideologies itself cannot and should not be avoided or contrasted to the word of God (Knitter, 1998, p. 182; Segundo, 1976, pp. 7-9). In that regard, Knitter points to the Christian tendencies of subordinating other cultural and religious traditions by maintaining the tone of superiority and domination in Christian doctrines even those that have the christological basis. He also reminds how the Third World Asian theologians have been aware and reminded the theological discourses especially in the West about how even the so-called inclusive theology such as "anonymous Christian" by Rahner and the liberal one such us critical catalyst by Kung still promote a "crypto-colonialist theology of religions and "cultural imperialism of the West (Knitter, 1998, p. 182; Kung, 1976; Rahner, 1974). In this regard, talking about theology universally 
in global context and particularly in the context of third world countries, the most often asked question in interreligious dialogue about the common ground or anything that bounds the religions of the world could be answered by liberation theology of religions. As Knitter offered, if there is no pre-established common ground that can be invoked before dialogue, there is perhaps a common approach or a common context to begin dialogue, in order to make the shared "shaky ground" which he calls a shared locus of religious experience, instead of searching for the one God or the common essence or the mystical center within all religions (Knitter, 1998, pp. 185186).

In a similar way with that of in theological framework, within the framework of religious studies, Knitter proposes the idea of cooperating interreligious dialogue with social action. He emphasizes that something crucial will be missing if both do not really get together in endeavoring to realize their goals effectively. In that proposal he defines interreligious dialogue as a particular way of interacting with others in which people talk and challenge each other, agree and disagree with one another so that they can grow in a fuller understanding of reality or truth. Meanwhile, social action is understood as "any activity that seeks to do something about the suffering that results when some human beings harm other human beings or the natural world for purposes of their own gain" (Knitter, 2013, p. 133; Lattu, 2019a, p. 72; Swidler, 2014, p. 377). In this regard, under the framework of Vatican Council's categorization of dialogue, the dialogue of action where participants get their hands dirty together becomes Knitter's main focus. In realizing that dialogue, Knitter adds the five main virtues necessary for interreligious dialogue by quoting Catherine Cornille (2008); humility, commitment, trust, empathy, and hospitality (Knitter, 2013; Lattu, 2019a, p. 72).

Knitter makes detailed strong argumentations about the reason why interreligious dialogue needs social action and vice versa. At the very base, religion he argues has been part of the problem, such as suffering, that should be responded to. Religion in this sense has contributed to that by taking sides with the perpetrators of it or at least religion has served as a distraction from this suffering. However, religion still has the chance to be part of the solution. In this regard, the relevance and significance of religion to the common challenges should be taken into account. The main reason is that the complex problems nowadays that need the attention and action of religions are global and thus the solutions also must be global, since no single group could singlehandedly overcome the interconnected issues. In addition, the role of religion is very important since people's life and responses to their world are always based on and motivated by their religious worldview (Knitter, 2013, p. 139). In ecological discourse for example, Lynn White argues that the way people treat nature around them is based on their (religious) worldview of how to perceive nature, and this kind of worldview is mainly provided by religion (White, 1967).

Lattu actually offers four forms of engagement; associational engagement, quotidian engagement, structural engagement, and symbolic-imagined engagement, but this work would limit the focus only on the two former concepts as the emphasis of the topic although the aspects of structural engagement, which deal mostly with political power/structural interventions in the space of interreligious interaction, and of symbolic-imagined engagement, which deals with how symbols and rituals could go beyond face-to-face or physical interaction, actually could also be explored in the engagement of Christians and Marapu. The first model discussed in this work, associational engagement, implies a form of an established association of interreligious communities by which different religions jointly address common concerns based on their shared similar attitudes and values. This kind of engagement could be divided into the bourgeois sphere or engagement, that links to theological discussion based on religious 
clerical conversations about sacred texts, and the common concern-non textual engagement, that based on people's social networks in everyday encounters (Lattu, 2014 , p. 228, 2016, p. 180). That idea of bourgeois sphere is in line with Knitter's commentary on the elite conversations that have become either a distraction from, or an indirect support of, the economic and political realms of injustice and exploitation (Knitter, 2013, p. 139).

The second model, quotidian interreligious engagement, emerges from everyday relationships in which everyday interactions contribute to make the common ground for people with different social and religious backgrounds since constant encounters in everyday face-to-face relationships result in mutual awareness of the people involved in. This kind of common concern-based dialogue does not necessarily deal with religious themes (Goffman, 1980, pp. 8-13; Lattu, 2014, pp. 229-230; Varshney, 2001, p. 9). In addition, Knitter's concern on this discussion about common ground is also depicted in his quotes on Cobb and Panikkar who use the Habermasian approach in arguing that common ground or shared viewpoints will be discovered or created in the very praxis of communication (Knitter, 1998, p. 184). Lattu also quotes Eck saying that dialogue of life or dialogue in community is based on people's daily activities and ordinary relationship and the everyday activities will create cultural capital for interreligious engagement and a reflective understanding of in-group communication (Eck, 1998, p. 13; Lattu, 2016, p. 171; Swartz, 1997, p. 141; Terry Rey, 2007, pp. 51-53).

In line with Lattu's point about engagement, Knitter ends his proposal of engaging interreligious dialogue with social action by offering some guidelines for what he calls "Socially Engaged Dialogue." First, compassion, implying the shared feeling of different religious people in what he calls "suffering (together) with." Second, conversion, implying the shift from selfcenteredness to centeredness on others. Third, collaboration, implying the need to find the best or the most appropriate response to remove suffering in certain contexts from different perspectives of religions without any intention to point out who is better than who. Fourth, comprehension, implying the importance of the hermeneutical circle between praxis and theory. Fifth, communion, implying the need to "come together" to find deeper unity in some forms of ritual. In short, such socially engaged interreligious dialogue could be accentuated by both "top-down" and "bottom-up" process but especially bottom up. In a more concrete suggestion, Knitter proposes Grassroots Multi-religious Communities (GMCs) (Knitter, 2013, pp. 144146). This is in line with Lattu's idea about the everyday engagement as the basis of interreligious relationship, rather than the theological conversations of the elites and religious leaders.

\section{Manawara as a Shared Virtue}

Shared indigenous knowledge is the background for ritual performance in which participants of the ritual comprehend meaning of the event and foster social integration (Lattu, 2014, p. 101). If in Maluku ritual performance becomes one instrument to revive the collective memory of the "kinship relationship", orang basudara, across lines of religion and of community after the conflict there from 1999 to 2004, in Sumba the kinship relationship is not only exist as a collective memory of the past, but the kinship relationship itself among Sumbanese Christians and Marapu is still there up to now. The ritual performance such as agricultural activity and joint harvest and other familial ceremonial events also become the space in which shared indigenous knowledge is reimagined and social integration is strengthened. However, manawara itself is lived not only in special or certain occasions as mentioned before. Instead, it is lived in everyday engagement anywhere at any time and thus even makes it seldom mentioned as a teaching except in certain religious events but it is always depicted in that everyday encounter.

As the teaching of love in Christianity 
must have been clear and it is a teaching that people mostly have been familiar with, this work only explores the core of manawara in Marapu and the way it is addressed by Sumbanese Marapu and Christians in their everyday engagement. In the teaching of Marapu religion, manawara, the teaching inherited from the first ancestors of Sumbanese, Umbu Bobo-Umbu Kamou, implies the tenet to love other human beings and the non-human beings. The main contents of this teaching are manawaradi ole atamu, meaning "love your neighbor," and manawaradi pawaimu, "meaning love anything you have (around you)." The former is depicted in the harmonious life and many forms of cooperation in the everyday life of Sumbanese Marapu and Christians such as building houses, building custom homes, familial events, agricultural activities, and many more. One visible strong evidence of harmonious life is, in many places, Sumbanese have the small village called wanno in which there are some houses of both Marapu people and Christians forming a circle encircling a batch of grave stones in the center (Deta, 2019, pp. $3,19)$. This is an indication of how their everyday engagement occurs.

There are almost no boundaries and it is hard to differentiate who belongs to Christianity and who belongs to Marapu. Only when the Marapu people do their ritual then the Christians dissociate themselves from the event since there is a prohibition from the church for Christians to join any kind of Marapu rituals. Meanwhile, the Marapu people could and often join Christian worship both in a Christian house and even in the church. The basis of this is a teaching saying mai mbara yame, kako mbara ne, meaning "they come to (visit) us here, we also go to (visit) them there" (Deta, 2019, pp. 20, 23, 25). This is a sign of how inclusive the Marapu people are especially when I have the experience in which the Marapu Rato (religious leaders), after having interview with me, invited me to enter his house which is the sacred house of Marapu to have a lunch and asked me to lead the pray in Christian ways. In this regard, I would argue that there is no strict boundary actually to differentiate Sumbanese Christians doing their teaching of love according to the gospel and Sumbanese Marapu doing their teaching of manawara according to their indigenous virtues (Deta, 2019, p. 26).

Although that argument implies the equality of the manawara of Christians and that of Marapu regardless of the different sources of it and the different ways of maintaining it, orally and textually, the main challenge is that many Christians still perceive Marapu indigenous religion as inferior. They also perceive orality and oralbased community as inferior, even though actually they are ironically rooted and merged as well in that oral-oriented community. Examining with Bevans' modes of contextual theology, the attitudes of Sumbanese Christians toward Marapu religion, people, and teaching such as manawara, tend to use the translation and the counter-cultural modes, because of perceiving their written scripture and doctrinal traditions as the perfect one so it could and should perfect the "imperfect" manawara and discover its deficiency with Christianity as the prototype (Deta, 2019, p. 34). In line with that, the mission of Christians mostly is to transform the teaching of Marapu and to convert the people to be Christians. In this regard, the following sections will try to rethink the inferiority of orality and oral-based community, and the shifted paradigm of mission in Christianity.

\section{Revisit the Inferiority of Orality and Oral- based Community}

Scripture as the written stuff of many world religions is often mentioned in the discourse of religions and even used as the main guidelines of determining certain attitudes towards any issue. For example, seeing the reluctance of bringing the scripture-based theological contentions into dialogue, Abu Nimer reminds the importance of scripture and sacred text which could enrich interfaith dialogue and provide a level of "certainty" and "truth" 
so that it could function as a foundation providing direction and confidence (AbuNimer, 2002, p. 19). However, as mentioned before, Lattu argues that orality could be more appropriate and effective than the scriptural tradition in building interreligious relationships especially in oral-oriented society. The main challenge of arguing such contention is the inferiority of orality including the oral-based community itself as happened in the case of Marapu. The academic paradigm dominating public discourse puts the ability to write and read as one sign of advancement of civilization, while those oral-based societies and all their worldviews are considered as the sign of backwardness and primitiveness. Meanwhile, in the political discourse, especially the politic of religion, there has been so-called definition or categorization of what could be counted as religion or agama in Indonesia namely believing in one God, having a prophet, and having a scripture with structured system of belief (S. Maarif, 2017, p. 25). Hence, mostly indigenous religions in Indonesia become the differentiated inferior groups. This is also one reason that they often are not involved in the discourse of interreligious dialogue due to their status as merely culture or kepercayaan (belief). In this regard, Lattu and Knitter's contentions found its relevance.

Within the theological framework, Lattu proposes what he calls as "Theology without In $k^{\prime \prime}$ addressing the trend of ink imperialism which actually inherited from colonialism with their mission of civilizing the third world country by also bringing religion (Christianity) as the supportive part of it. Ink imperialism arguably refers to the superiority of the scripture by which many mainstream Christians being trapped in their scripture and Church tradition as the only sources for theological and church discourses. In this regard, Lattu insists that in order to overcome the issue, deconstruction is at the very base of the transformative steps. To reject ink imperialism, he argues, the text (scripture) should be deconstructed so that the local text could find its space to be developed. He adds that the problem of paradigm in the Christian theological discourse is the perspective of rationality which perceives theology as limited only in the space of mind and ratio and refusing observation and experience as the important basis for theology. The underlying assumption of this notion is that "text" is much broader than merely "writing" because "text" is message, not ink (Lattu, 2020, pp. 89-91).

Lattu reminds that Indonesian oraloriented societies just recognize "message in ink" through business, political, and religious encounters in the era of the trade of spices, but the power of ink does not strictly apply on the society with indigenous knowledge and theology in their collective memory (Lattu, 2020, p. 91). This does not only happen in the colonial era but until now there are many cases in Sumba and other places in which the oral-oriented societies, although cannot write and read, have the richness of worldviews which have been maintained through oral transmission, being repeated in ritual, and being kept in the collective memory. Lattu adds that when literacy enters into an oral society, the written model of communication does not remove the significance of the oral tradition but rather strengthens it (Lattu, 2019c, p. 95). He quotes Ong saying that writing from the beginning actually never reduced orality but rather enhanced it (Lattu, 2019c, p. 96; Ong, 2003, p. 9).

Exploring further Ong's contention, Lattu finds out that the characteristics of orality include "additive rather than subordinative, aggregative rather than analytic, redundant or 'copious', conservative or traditionalist, close to the human lifeworld, agonistically toned, empathetic and participatory rather than objectively distanced, homeostatic, and situational rather than abstract" (Lattu, 2019c, p. 96; Ong, 1980, p. 128). In comparison to the textual traditions, orality is arguably closer to the human life world because it continuously shapes its meaning and structure from real social life experiences (Lattu, 2019c, p. 97; Ong, 1980, 
p. 130), and thus always contextual and relevant. It is different with textual form in which meaning and message are trapped in the text so that hermeneutics and interpretation become very pivotal in trying to get the message. Since oral culture maintains its knowledge by repeating it and not by writing it (Lattu, 2019c; Ong, 1988, pp. 259-269), the process of contextualization occurs along with the process of transmitting it from one generation to the next generation according to their current context. As Ong argues, redundancy, or repetition of that which has been just said, keeps both the speaker and the hearer surely on track (Lattu, 2019c; Ong, 1980, p. 40). In brief, the inferiority of both orality and oral-oriented society should be perceived as a long-standing construction that has undermined the richness of many distinctively unique localities.

\section{The Encounter of Christianity and Marapu}

In Sumbanese context, the absence of written and structured or systematic teaching of Marapu religion and the low rate of education of its followers made it hard to be defended against Christianity with its scripture and its highly educated adherents (Deta, 2019, pp. 1, 22; Ukur \& Cooley, 1979, p. 333). This encounter with Christianity has been started since the colonial era with the coming of the missionary and then results in the establishment of the Christian Church of Sumba (Gereja Kristen Sumba) in which until now Christianity becomes one of the major religions that is very influential in Sumba (Keane, 2007, p. 8; Wellem, 2004). As explored in the previous part, since the first encounter, the imbalance of power relation between the superior and the inferior has colored the engagement, although in the concrete personal daily relations, regardless of the exclusive theological assumption of Christians which mainly imposed by the church as an institution, the engagement has no conflicts especially whose base is religion. The fact that Marapu people are still perceived as inferior, having no religion yet, and thus should be Christians (Mubarak, 2021, p. 4) is at the very base of the current challenges. This is seen in how the Church perceives the meaning of mission or evangelization by emphasizing the importance of conversion from nonChristian to be Christians.

As theological discourse of missiology has developed, the meaning of mission actually has sifted. As N. J. Woly argues, missiology will come into reality only if it takes the theology of religions as its main supportive pillar. He adds that the main purpose of missiology is to study and endeavor an understanding of how a creative and critical interaction can happen in between theology of religions from the Christian perspective and theology of religions from the non-Christian perspective of faith (Wolly, 2010, pp. 556-558). In this regard, perceiving this idea of the interconnectedness of missiology with theology of religions cannot be separated with Knitter's notion of the cooperation between theology of religions or interreligious dialogue with theology of liberation or social action. Putting those at the same board of discussion, necessary steps to develop the form of interreligious engagement between Christianity and Marapu could be identified under the concept of mutual engagement in which there is equal power relation between them with a set of virtues necessary in socially engaged dialogue.

As Lattu insists, it is hard to imagine a form of mutual engagement in a society in which there is unequal superior-inferior position among different religious people where some groups have claimed the position of zone of being while putting another group into the zone of non-being (Lattu, 2016, p. 175). This impetus to have mutual engagement aims to gain nothing else but the mutual transformation with an awareness and recognition, or even confession, that in Christianity itself from the very beginning of its early coming, mutual transformation has taken place even since the time of Jesus (Lattu, 2019b, p. 3). Besides, major parts of Christian teaching in early Christian history in its establishment and development, had absorbed Greek 
philosophy as well as Greek and Roman cultures to develop Christian church' credo (Lattu, 2019b, p. 4). Therefore, there is no reason to refuse the need, or to be more precise, the opportunity to gain mutual transformation in the interreligious engagement that is based on a common indigenous knowledge like manawara. If it is said that in mutual transformation, religious adherents have a great chance to understand and interact deeply with other religious people (Lattu, 2019b, p. 19), Sumbanese actually have been arguably one step closer because what they need to do is just to be more open and humbler to equally recognized one another.

\section{Conclusion \\ The Call for Common Liberation: An Inviting Conclusion}

Changing the direction and the tone of the engagement of Sumbanese Christians and Marapu will bring the community to further steps of endeavoring mutual action for common liberation, based on the shared virtue of manawara. The Sumbanese Christians and Marapu actually have lived their interreligious engagement with almost all forms of dialogue proposed and identified by scholars. At the very core of their everyday engagement, they maintain their (religious and cultural) worldview and realize it in their practices. In this regard, dialogue of heads, hearts, and hands, as well as dialogue as conversation and dialogue as praxis have been conducted. This certainly should be taken into account by the religious institutions especially the church. In line with Lattu's contentions have been explored before, the Church as an institution needs to take a look at the grassroot initiative and practices on interreligious engagement. This grassroot mode of engagement is an important capital to develop the interreligious engagement at any extent; formal and informal, grassroot and elite, the religious people and the religious leader, and so on. In short, in spite of the top-down model, in which the institution dictates the grassroots by for example making such prohibition of joining Marapu ritual, the bottom-up model should be maximized to the fullest.

As everyday engagement results in the awareness of being interconnected and thus having the same challenges, in short common ground and common problems, Knitter's proposal on initiating such Grassroot Multi-religious Communities (GMCs) becomes important. The harmonious life of Sumbanese Marapu and Christians has to move further to not only enjoy such interreligious relationships, but rather identify and jointly respond to the common challenges. Their dialogue of hand might have been practiced through many forms of cooperation among them, but then the more underlying and urgent problem should be taken into account since they have the opportunity; the common ground. Sumbanese in general as well as its various contexts of different places have some longstanding urgent social problems such as poverty and especially discrimination against the Marapu community as the oftenstigmatized minority. This social problem is inseparable with religious (Christians) discourse. Hence, mutual engagement for mutual transformation in which equality and justice are upheld is very necessary. As Abu-Nimer argues, the successful outcome of any concrete project will contribute to the development of the minorities and will provide them with much-needed credibility and support for their efforts to engage in an interfaith dialogue forum. He adds that the underlying assumption of engaging religions for common liberation is that the spiritual, moral, and ethical components of any religious identity are powerful sources for generating change (Abu-Nimer, 2002, pp. $24,29)$. In this regard, Sumbanese religions, like Christianity and Marapu, are perceived as having potential significance in responding to the social problem as long as they could maintain and develop further their shared virtue and mode of interreligious engagement, in order to gain the mutual transformation in terms of paradigm and concrete situation of their socio-cultural life. 


\section{Acknowledgments}

In publishing this article, I firstly thank the Center for Religious and Cross-cultural Studies (CRCS), Graduate School, Universitas Gadjah Mada, for providing me the academic space to do my master study with a scholarship funding for my tuition fee. Secondly, I thank Izak Y. M. Lattu, Fatimah Husein, and Paul Martens (from Baylor University) as the lecturers of the subject "Interreligious Dialogue: Theories and Practices" in CRCS, for inspiring me to write this article. Thirdly, I thank the people of Weelimbu Village in Sumba, both the Marapu and Christians for allowing me to do my research there. Fourthly, I thank Cindy Q. Koan as my advisor in the Faculty of Theology, Universitas Kristen Satya Wacana, when doing the research in 2019. Finally, I thank the Journal of Dialogue for giving me the chance to publish this paper and make it available for more readers.[]

\section{Bibliography}

Abu-Nimer, M. (2002). The Miracle of Transformation through interfaith dialogue; Are you a believer?". In David R. Smoch (Ed.), Interfaith Dialogue and Peacebuilding. United States Institute of Peace Press.

Banawiratma, J. B. (2002). Washington DC: United States Institute of Peace Press. In A. Race \& I. Shafer (Eds.), Religious in Dialogue: From Theocracy to Democracy. Ashgate.

Deta, K. U. (2019). Kajian Teologi AgamaAgama yang Kontekstual mengenai Sikap Orang Kristen di GKS Ngamba Deta terhadap Eksistensi Penganut Marapu dan Ajaran Manawara. Tugas Akhir [Universitas Kristen Satya Wacana, Salatiga]. https://repository.uksw.edu/ handle/123456789/20192

Eck, D. (1998). Interreligious Dialogue as a Christian Ecumenical Concern. Columbia University Press.

Eck, D. (2017). Interfaith Dialogue in the New Religious America. Review and
Expositor, 114(1), 25-33.

Goffman, E. (1980). The Presentation of Self in Everyday Life. Penguin.

Keane, W. (2007). Christian Moderns: Freedom and Fetish in the Mission Encounter. University of California Press.

Knitter, P. (1998). Toward a Liberation Theology of Religions. In J. Hick \& P. Knitter (Eds.), The Myth of Christian Uniqueness. Toward a Pluralistic Theology of Religions (7th ed., pp. 178-218). Maryknoll.

Knitter, P. (2013). Inter-Religious Dialogue and Social Action. In Catherine Cornille (Ed.), The Wiley Blackwell Companion for Interreligious Dialogue (pp. 133-148). MA: Wiley-Blackwell.

Kung, H. (1976). On Being a Christian. Doubleday.

Lattu, I. Y. (2014). Orality and Interreligious Relationships: The Role of Collective Memory in Christian Muslim Engagements in Maluku, Indonesa. California: Graduate Theological Union, Berkley.

Lattu, I. Y. (2016). A Sociological Breakthrough of Interreligious Engagement in Everyday-Symbolic Interaction Perspectives. Religio: Jurnal Studi Agama-Agama, 6(2), 164-185.

Lattu, I. Y. (2018). Halal Bihal in Javanese Interreligious Family Perspective.

Lattu, I. Y. (2019a). Beyond Interreligious Dialogue: Oral-Based Interreligious Engagements in Indonesia. In G. Giordan \& A. P. Lynch (Eds.). Annual Review of Sociology of Religion Vol. 10: Interreligious Dialogue (pp.70-90). Brill.

Lattu, I. Y. (2019b). Mutual Transformation in the Early Histories of Christianity and Islam. Qudus International Journal of Islamic Studies, 7(1).

Lattu, I. Y. (2019c). Orality and Ritual in Collective Memory: A Theoretical Discussion. Jurnal Pemikiran Sosiologi, 6(2), 94-111. 
Lattu, I. Y. (2020). Teologi Tanpa Tinta. In F. Purwanto \& A. T. E. Warsono (Eds.), Membangun Gereja Sebagai Gerakan Yang Cerdas Dan Solider. Sanata Dharma University Press.

M. Gopin. (2002). The Use of the Word and Its Limits: A Critical Evaluation of Religious Dialogue as Peacemaking. In David R. Smoch (Ed.), Interfaith Dialogue and Peacebuilding. United States Institute of Peace Press.

Maarif, A. S., Magnis-Suseno, F., \& Zehermair, H. (2010). Ethics and Religious Dialogue in a Globalized World. the Habibie Center.

Maarif, S. (2017). Pasang Surut Rekognisi Agama Leluhur dalam Politik Agama di Indonesia. CRCS UGM.

Mubarak, H. (2021). Advokasi Inklusi Sosial: Praktik Baik Advokasi Penghayat Marapu di Sumba, Nusa Tenggara Timur (seri monog). The Asia Foundation.

Ong, W. J. (1980). Literacy and the Future of Print: Literacy and Orality in Our Times. Journal of Communication, Winter, 197-204.

Ong, W. J. (1988). Before Textuality: Orality and Interpretation. Journal of Oral Tradition, 3 (3), 259-269.

Ong, W. J. (2003). Orality and Literacy. Routledge.

Rahner, K. (1974). Anonymous Christianity and the Missionary Task of the Church. In Theological Investigations (Vol. 12, pp. 161-178). Seabury.

Segundo, J. L. (1976). The Liberation of Theology. Orbis Books.

Swartz, D. (1997). Culture and Power: The Sociology of Pierre Bourdieu. The University of Chicago Press.

Swidler, L. (2013). The History of Interreligious Dialogue. In Catherine Cornille (Ed.), The WileyBlackwell Companion for Interreligious Dialogue (pp. 1-20). Malden, MA: WileyBlackwell.
Swidler, L. (2014). Sorting Out Meanings: 'Religion,' 'Spirituality,' 'Interreligious,' 'Interfaith,' ETC. Journal of Ecumenical Studies, 49(3), 373-383.

Terry Rey. (2007). Bourdieu on Religion: Imposing Faith and Legitimacy. Equinox Publishing Ltd.

Ukur, F., \& Cooley, F. L. (1979). Jerih dan Juang: Laporan Nasional Survei Menyeluruh Gereja di Indonesia. Lembaga Penelitian dan Studi - Dewan Gereja Indonesia.

Varshney, A. (2001). Ethnic Conflict and Civic Life: Hindus and Muslims in India. Yale University Press.

Wellem, F. D. (2004). Injil dan Marapu: Suatu Studi Historis-Teologis tentang 